pressing questions in the 1990s. This stage is characterized by a series of fundamental questions concerning the formation and development of an independent rule of law and a national legal system in fundamentally new socio-political realities not only within the national legal space but also within the European space; the mechanism of interaction between the national legal system and the legal system of the Council of Europe; peculiarities of systematization and unification of legislation at the stage of formation of the legal system of Ukraine. At the beginning of the second decade of the XXI century. begins the third stage in the formation of the theory of the legal system, which will be the subject of research in the next article.

Key words: globalization, interstate legal system, international legal system, national legal system, law, legal system, theory of legal system.

DOI: $10.36695 / 2219-5521.3 .2019 .02$

УДК 340.12

\title{
B.C. БІГУН
}

В'ячеслав Степанович Бігун, кандидат юридичних наук, магістр права (США), науковий співробітник Інституту держави і права ім. В.М. Корецького НАН України*

ORCID: 0000-0003-0108-0578

\section{ДОБРОЧЕСНІСТЬ ЯК ПРАВОВИЙ РЕЖИМ І ПРАВОВІДНОСИНИ}

Проблематика доброчесності - доброчесність як явище, категорія і загалом дискурс - актуалізується в Україні після подій 2013-2014 pр., акцентуючи увагу на етичному вимірі соціальних перетворень. У попередніх публікаціях ми обгрунтували постановку питання про доброчесність як принцип правосуддя, запропонували періодизацію сучасного правознавчого дискурсу доброчесності та її розгляд як нормативно закріпленої інституційної об'єктивації чесноти в сфері правосуддя, розглянули генезу їі інституціоналізації, окреслили проблематику доброчесності в створенні Вищого антикорупційного суду1 1 спробували розкрити доброчесність як термін та його смисл.

Наш аналіз виявляє: на даному етапі доброчесність упроваджується у суспільну практику не тільки і не стільки через механізми моралі, етичні норми та їхнє здійснення, як через юридизацію етики шляхом законодавчого впровадження категорії доброчесності. Прийнято вважати, що мораль відрізняється від закону тим, що, як правило, не забезпечується засобами державного примусу. Проте під час нового витка судової реформи в Україні, як зазначалося, відбувається «юридизація моралі» (етики), коли відповідні норми (зокрема суддівської етики) регламентуються законом, набуваючи правового статусу. Доцільність цього в Україні зумовлюється потребами суспільної практики, які, як уявляється, згідно з певним соціальним консенсусом чи компромісом, у більш ефективний спосіб повноцінно забезпечити наразі не вдалося.

Мовою теорії права поступово формуються ознаки правового режиму в сфері юридичної етики, доброчесності у судовій діяльності. Про це свідчить особливий порядок правового регулювання, який поєднує юридичні засоби, і ширше, елементи правового впливу для створення бажаного соціального стану. Виклад змісту цього режиму - мета публікації.

Поняття «правовий режим» залишається дискусійним². Зважаючи на це, але не вдаючись до дискусії, зазначимо, що ми використовуємо найбільш загальне поняття правового режиму як особливого порядку правового регулювання певної сфери суспільних відносин, забезпеченої певними методами, способами і типами такого регулювання 3 . По суті це означає, що правовий порядок регулювання відносин доброчесності забезпечується специфічними засобами правового регулювання.

Про наявність правового режиму зі здійснення доброчесності свідчать такі його риси за теорією такого режиму: встановлення законодавством (Конституцією, законами) і гарантованість (забезпечення) державою, державним примусом; мета - регламентування певної сфери суспільних відносин - судової діяльності конкретних суб'єктів та об’єктів права; правове регулювання за допомогою певних юридичних засобів; певний ступінь сприятливості (несприятливості) для задоволення інтересів суб'єктів права - наявність певних обмежень чи заборон тощо.

Щодо методів правового регулювання, то використовуються всі чотири: імперативний, диспозитивний, рекомендаційний та заохочувальний.

Далі з'ясуймо обсяг юридизації суддівської етики та доброчесності, проаналізувавши відповідні нормативно-правові акти 4 .

Ключовим юридичним інструментом нормативного законодавчого впровадження суддівської юридичної етики став Закон «Про судоустрій і статус суддів» (2016р.). Зокрема, у ст. 56 Закону «Права та обов’язки

(C) В.С. Бігун, 2019 Ukraine

* Vyacheslav Bihun, Ph.D. in Law, Master of Laws (USA), Researcher of V. M. Koretsky Institute of State and Law of the NAS of 
судді» міститься положення, яке істотно змінює зміст обов'язку за критерієм доброчесності, а саме обов'язок судді «подавати декларацію доброчесності судді та декларацію родинних зв'язків судді» (ч. 7 ст. 56). Закон встановив обов'язок самооцінки доброчесності шляхом декларування.

Зміст декларації доброчесності визначається положеннями ст. 62 Закону. Так, суддя зобов’язаний щорічно до 1 лютого подавати шляхом заповнення на офіційному веб-сайті Вищої кваліфікаційної комісії суддів України (далі - ВККС, Комісії) декларацію доброчесності за формою, що визначається Комісією, і яка є відкритою для загального доступу через оприлюднення на веб-сайті.

Згідно з приписами Закону декларація складається з переліку тверджень, правдивість яких суддя повинен задекларувати шляхом їх підтвердження (непідтвердження). У декларації зазначаються прізвище, ім'я, по батькові судді, його місце роботи, займана посада та твердження про: 1) відповідність рівня життя судді наявному в нього та членів його сім’ї майну і одержаним ними доходам; 2) своєчасне та повне подання декларацій особи, уповноваженої на виконання функцій держави або місцевого самоврядування, та достовірність задекларованих у них відомостей; 3) невчинення корупційних правопорушень; 4) відсутність підстав для притягнення судді до дисциплінарної відповідальності; 5) сумлінне виконання обов'язків судді та дотримання ним присяги; 6) невтручання у правосуддя, яке здійснюється іншими суддями; 7) проходження перевірки суддів відповідно до Закону України «Про відновлення довіри до судової влади в Україні» та їі результати; 8) відсутність заборон, визначених Законом України «Про очищення влади».

За Законом Декларація може містити інші твердження, метою яких є перевірка доброчесності судді.

У процесі розробки декларації Комісія сформувала та розширила зміст критерію доброчесності. Зокрема, якщо Закон містить вісім (8) позицій, то в Декларації, затвердженій Комісією, їх деталізовано в двадцяти трьох (23). Наприклад, додано такі два положення: «Мною не здійснювалися витрати, що перевищують мої доходи» та «Членами моєї сім’ї не здійснювалися витрати, що перевищують наші доходи». Припускаємо, що суддя, якщо він чи/та члени його сім'ї здійснювали такі витрати (наприклад, отримання кредиту для, умовно, великих придбань), тепер зобов'язаний це задекларувати та пояснити.

Текст затвердженої Комісією Декларації містить і таке положення: «Майно, що належить мені або членам моєї сім’ї на праві володіння, користування або розпорядження, було набуто із законних джерел». При цьому Правила заповнення та подання форми декларації встановлюють, що «У разі заповнення Декларації вперше у ній зазначаються твердження щодо обставин, які мали місце упродовж усього життя особи, яка їі заповнює».

Крім того, у затвердженій Декларації розширено твердження щодо втручання (невтручання) у здійснення правосуддя. Так, якщо Закон зобов’язує суддю підтвердити чи спростувати, що «Випадків мого втручання у правосуддя, що здійснювалося іншими суддями, не було», то Декларація містить і такі твердження: «Випадків втручання у мою діяльність по здійсненню правосуддя не було» і, окремо, «Мною вживалися заходи щодо повідомлення відповідних органів про випадки втручання у мою діяльність щодо здійснення правосуддя».

Більше того, Декларація тепер охоплює такі загальні твердження, як-от: «Мною дотримувалися положення професійної етики»; «Мною не здійснювалися вчинки, що можуть мати наслідком притягнення мене до відповідальності»; «Мене не було притягнуто до відповідальності за вчинення проступків або правопорушень, які свідчать про недоброчесність».

Зміст цих положень також засвідчує, що Декларація доброчесності охоплює і положення професійної етики.

Як і раніше, згідно з міжнародними стандартами, сфера застосування професійної суддівської етики охоплює як професійну судову, так і позасудову діяльність.

Важливо, що така Декларація подається й кандидатами на посаду судді.

Особа, яка декларує, нестиме відповідальність за всі твердження, які зазначені в Декларації, що стосуються усього попереднього професійного та приватного життя.

Результатом такої правової регламентації стало законодавче закріплення юридичної відповідальності за дотримання положень юридичної (суддівської) етики та доброчесності, зокрема охоплення останньою суддівської етики. При цьому положення доброчесності почали охоплювати такий зміст, що має стосунок не загалом до «моральної поведінки особи», як етимологічно трактується цей термін (хоча така поведінка може припускатися), а іiі поведінки з акцентом чи такою, яка пов'язана значною мірою з ії матеріальним (майновим) становищем. Як зазначалося, режим доброчесності поширено як на сферу суддівської, так і позасуддівської діяльності, й такої, яка передувала суддівській діяльності (зокрема й щодо кандидатів на посаду).

Так законом впроваджено суворе регламентування етичних норм у сфері суддівської діяльності, а ефективність цього виявить подальша практика його застосування.

Наступним подамо аналіз структури (складу) правовідносин. Оскільки відносини щодо критеріїв доброчесності та юридичної етики мають ознаки правовідносин чи є такими в Україні, тобто виражаються у певних правах і обов’ язках суб’єктів права, то задля методологічної стрункості викладу доцільно здійснити подальший їхній виклад, без претензій на вичерпність, на основі аналізу структури (складу) правовідносин суб'єктів, об'єкта, змісту, інших елементів, притаманних юридичному аналізу.

Суб 'єкти. Суб'єкти чи суб'єктний склад - це особи, які беруть участь у відносинах, зокрема, правовідносинах щодо забезпечення дотримання доброчесності та юридичної етики. Такими є передовсім правозобов 'язані сторони - особи, які є претендентами, - як діючі судді, так і кандидати на посаду судді. Такими ж 
особами є й правомочні сторони, переважно державні органи та їхні уповноважені особи, - ВККС, Громадська рада доброчесності (далі - ГРД), Вища рада правосуддя, Президент України, а також інші державні органи, які вступають у певні аспекти цих правовідносин (наприклад, органи, задіяні в проведенні перевірок). Окремим питанням є правосуб'єктність таких органів, що варто розглянути в окремому огляді.

До кола правозобов 'язаних сторін можна віднести й членів сім'ї судді (чи кандидата на посаду). Закон зобов'язує останніх забезпечити «відповідність рівня життя судді наявному в нього та членів його сім’і майну і одержаним ними доходам», а практика правозастосування трактує це положення ширше, зокрема зобов'язуючи суб’єкта відповісти на таке твердження в Декларації доброчесності: «Членами моєї сім'ї не здійснювалися витрати, що перевищують наші доходи». Наразі практика ще формується 3 цього питання, зокрема й щодо того, чи покладатиметься відповідальність (якщо так, то яка) за дотримання та порушення цього положення й на членів сім'ї, чи лише на суддю (кандидата на посаду судді).

Об 'єкm. Об'єктом зазначених правовідносин - тобто того, з приводу чого виникає і здійснюється діяльність суб'єктів, - є принципи, норми професійної етики та складові обов'язку доброчесності. При цьому обсяг цього об'єкта наразі потребує конкретизації у частині змісту та практики застосування. Умовно вони розділені на ті відносини, які стосуються критерію доброчесності, та ті, які стосуються критерію професійної етики.

Важливо, що розуміти під терміном «професійна етика». Припускаємо, що йдеться про загальний термін «юридична етика», який стосується етики юриста загалом. Водночас до суддів застосовується спеціальна професійна етика - суддівська.

Доброчесність як об'єкm, попри уявну суб'єктивність, інколи може визначатися як об'єктивований (об’єктивний) показник ${ }^{5}$. Проявами (виявами) доброчесності є певні дії, які можна об'єктивно оцінити, та їхні наслідки.

Попри законодавчі визначення терміна «доброчесність», тобто його кодифікації, його зміст дискусійний, адже остаточно невизначений та продовжує формуватися. Адже зміст (як і функції) терміна доброчесність, як нами доводилося раніше, є багатозначним. Доброчесність, наприклад, виступає як один із критеріїв відповідності суддівській посаді, як превентивний засіб у боротьбі з корупцією, як якісна характеристика державної установи (суду) - оціночна якісна діяльності, як принцип судової діяльності - діяльності судді, як принцип етичної поведінки судді (кандидата на посаду), як принцип і стандарт етичної поведінки у виконанні повноважень

Зміст (обсяг) та об 'єктивна сторона. Зміст цих правовідносин формують суб'єктивні права, обов'язки, повноваження, відповідальність суб'єктів таких відносин, а також структура змісту - спосіб взаємозв'язку, що виникає на їх підставі та в результаті їхньої взаємодії щодо доведення того, що претендент відповідає чи не відповідає критеріям доброчесності і юридичної етики. Таке юридичне становище суб'єктів визначається оцінкою поведінки в процесі реалізації їх прав і обов'язків з метою такого доведення. Об 'єктивна сторона таких правовідносин виявляється у певний діяннях (діях чи бездіяльності), поведінці відповідних суб'єктів.

Суб'єктивна сторона, як правило, розуміється як психічні процеси, які характеризують свідомість і волю особи в момент вчинення діяння. Так, певні діяння, поведінка (дія чи бездіяльність), що оцінюються на предмет відповідності критеріям доброчесності та юридичної етики, за суб'єктивною стороною стосуються ставлення суб'єкта до такої поведінки та можуть бути вчиненими умисно чи 3 необережності.

Складність дослідження суб'єктивної сторони полягає в тому, що вона недоступна для безпосереднього сприйняття чи спостереження, відтак іiї встановлюють за показаннями суб'єкта, на підставі аналізу та оцінки об'єктивованих ознак діяння.

Чи є обов’ язковою суб' єктивна сторона (і якою мірою) у діяннях (як у випадку кримінально-правового регулювання), які оцінюються на відповідність критеріями юридичної етики та доброчесності - ще потребує з'ясування на практиці.

Істотним є й та обставина, що діяння, які є предметом оцінки, могли відбуватися до того, як сталося нормативне (законодавче) закріплення правил юридичної етики та доброчесності (хоча, звісно, такі правила діяли й раніше, але з іншим статусом).

Юридичні факти. Підставою початку виникнення та зміни правовідносин є певні юридичні факти. Таким, наприклад, стало оголошення ВККС конкурсу на заміщення вакантних посад новоствореного Верховного Суду, Вищого антикорупційного суду та інших судів. Крім цього факту, мали місце й інші юридичні факти та обставини, як-от настання або ненастання певної події.

Презумпиії, критерії оцінювання та тягар доведення. За якими критеріями оцінюються доброчесність та моральні якості? Бангалорські принципи поведінки суддів (2006 р.) встановлюють «об'єктивний тест», за яким «суддя демонструє поведінку, бездоганну навіть 3 точки зору стороннього спостерігача». Подібне положення фіксує й чинний в Україні Кодекс суддівської етики (2013 р.): «Суддя має докладати всіх зусиль до того, щоб на думку розсудливої, законослухняної та поінформованої людини його поведінка була бездоганною» (ст. 3).

Діє презумпція достовірності. Так, за приписами закону Декларація доброчесності складається з переліку тверджень, правдивість яких суддя повинен задекларувати шляхом їх підтвердження або непідтвердження. За презумпцією достовірності, за відсутності доказів іншого твердження у декларації доброчесності, такі твердження вважаються достовірними (ч. 4 ст. 62 Закону). У разі одержання інформації, що може 
свідчити про недостовірність (в тому числі неповноту) тверджень судді у декларації, проводиться перевірка. Неподання, несвоєчасне подання декларації доброчесності суддею або декларування в ній завідомо недостовірних (у тому числі неповних) даних тягне за собою дисциплінарну відповідальність.

Окремий аспект - презумпиія не/доброчесності. Відкритими залишаються питання про те, чи вважається особа доброчесною допоки не доведено зворотного. Наприклад, як видається, громадські утворення, що досліджують доброчесності суддів (кандидатів), використовують презумпцію недоброчесності, за якою, у разі сумнівів, вони стверджують про недоброчесність, поширюючи таку інформацію через 3МI та наполягаючи на недопущенні особи до посади. Проте, як правило, такі утворення не подають визначення «доброчесності», натомість встановлюючи ознаки «недоброчесності», а ця процедура а також критерії спростування такого «статусу» (нерідко «тавра» на професійній репутації) не чітко сформульовані або знаходяться в стадії напрацювання. Позитивний громадський ефект такої діяльності не применшує важливість цих контроверсійних питань, які потребують додаткового дослідження.

Огляд уможливлює такі узагальнення. Доброчесність у судовій діяльності - сукупність етичних принципів і визначених законом правил, якими повинні керуватися учасники судової діяльності (зокрема судді) для забезпечення довіри до своєї діяльності (наприклад, здійснення правосуддя) - судового здійснення ідеї права.

Підтверджується теза про правовий режим доброчесності. Закріплення доброчесності як терміна і правових відносин у нормативно-правових актах, встановлення їі як етичного принципу щодо поведінки спричиняє не лише виникнення позитивного юридичного обов'язку доброчесності, а й правового режиму. Такий режим забезпечується специфічними засобами правового регулювання. Попри термінологічну проблематику (відсутність уніфікованого визначення доброчесності, різночитання, різнотлумачення, зокрема термінів «доброчесність» і «юридична етика», які подаються то спільно, то окремо), на практиці виникають правові відносини, аналіз яких, зокрема і наведений, покликаний удосконалити їхній правовий режим.

1 Див.: Бігун В.С. Доброчесність як принцип правосуддя: постановка проблеми та сучасний дискурс. Часопис Київського університету права. 2018. № 2. С. 29-33; Бігун В.С. Доброчесність як нормативно закріплена інституційна об’єктивація чесноти в сфері правосуддя. Часопис Київського університету права. 2018. № 3. С. 21-25; Бігун В.С. Вищий антикорупційний суд: філософсько-правовий аналіз формування незалежного суду і доброчесність конкурсу. Часопис Київького університету права. 2018. № 4. С. 26-32.

2 Див., напр., огляд дискусії: Вакарюк Л. Основні підходи до розуміння поняття правовий режим. Підприємнищтво, господарство і право. 2016. № 12. С. 196-201.

3 Див., напр., визначення: Загальна теорія права: підручник / за заг. ред. М.І. Козюбри. Київ, 2015. С. 101.

4 Дет. див.: Бігун В.С. Доброчесність як юридичний термін і сенс. Часопис Київського університету права. 2019. № 1. C. $25-29$.

5 Див., напр.: Європейські та міжнародні стандарти у сфері судочинства. Київ, 2015. С. 174.

\section{References:}

Bihun Vyacheslav. (2018). Dobrochesnist' yak pryntsyp pravosuddya: postanovka problemy ta suchasnyy dyskurs. Chasopys Kyivs'koho universytetu prava. 2, 29-33 [in Ukrainian].

Bihun Vyacheslav. (2018). Dobrochesnist' yak normatyvno zakriplena instytutsiyna ob"yektyvatsiya chesnoty v sferi pravosuddya. Chasopys Kyivs'koho universytetu prava. 3, 21-25 [in Ukrainian].

Bihun Vyacheslav. (2018). Vyshchyy antykoruptsiynyy sud: filosofs'ko-pravovyy analiz formuvannya nezalezhnoho sudu i dobrochesnist' konkursu. Chasopys Kyivs'koho universytetu prava. 4, 26-32. [in Ukrainian].

Vakaryuk Lyudmyla. (2016). Osnovni pidkhody do rozuminnya ponyattya pravovyy rezhym. Pidpryyemnytstvo, hospodarstvo $i$ pravo. 12, 196-201 [in Ukrainian].

Kozyubra M.I. (za zah. red.), (2015). Zahal'na teoriya prava: Pidruchnyk. K. [in Ukrainian]

Bihun Vyacheslav. (2019). Dobrochesnist' yak yurydychnyy termin i sens // Chasopys Kyivs'koho universytetu prava. 1, 25-29 [in Ukrainian].

Yevropeys'ki ta mizhnarodni standarty u sferi sudochynstva (2015). K. [in Ukrainian].

\section{Резюме}

Бігун В.С. Доброчесність як правовий режим і правовідносини.

Стаття подає аналіз ознак правового режиму та правовідносин доброчесності. Висвітлюється структура таких правовідносин: суб'єкти, об'єкт і зміст, інші елементи. Підтверджується теза про «юридизацію доброчесності» та динаміку формування правовідносин у сфері доброчесності в судовій діяльності.

Ключові слова: доброчесність, філософія права, загальна теорія права.

\section{Резюме}

Бигун В.С. Добропорядочность как правовой режим и правоотношения.

Статья представляет анализ признаков правового режима и правоотношений добропорядочности. Освещается структура таких правоотношений: субъекты, объект и содержание, другие элементы. Подтверждается тезис о «юридизации добропорядочности» и динамике формирования правоотношений в сфере добропорядочности в судебной деятельности.

Ключевые слова: добропорядочность, философия права, общая теория права. 


\section{Summary}

Vyacheslav Bihun. Integrity (Dobrochesnist) as a Legal Regime and Legal Relations.

The article provides an analysis of characteristics of the legal regime and legal relations of dobrochesnist (the Ukrainian term which may be translated as "integrity" or "good character"). The structure of such legal relations is outlined: subjects, object and content, other elements. The thesis of "legalization of dobrochesnist" and the dynamics of the formation of legal relations in the field of dobrochesnist in judicial activity are substantiated.

The issue of integrity, as a phenomenon, category and generally discourse, is actualized in Ukraine after the events of 2013-2014, focusing on the ethical dimension of social transformation.

Previously the author attempted to substantiate the issue of integrity as a principle of justice as a judicial process, suggested the periodization of modern jurisprudential discourse of integrity and its consideration as a normative institutionalized objectification of virtue in the field of justice, examined the genesis of its institutionalization, integrity as a term and its meaning, outlined the role of integrity in the process of the formation of the High Anticorruption Court in Ukraine.

Our analysis reveals that, at this stage, integrity is introduced into public practice not only and not so much through the mechanisms of morality, ethics and their implementation, but also the legalisation of ethics through the legislative introduction of the category of integrity. It is accepted that morality differs from the law in that it is usually not provided by means of state coercion. However, during the new round of judicial reform in Ukraine, as noted, there is a "moralization of morality" (ethics), when the relevant rules (including judicial ethics) are regulated by law, integrity acquiring a legal status.

In terms of theory of law, the characteristics of the legal regime in the field of legal ethics and integrity in judicial activity are gradually forming. This is evidenced by the special order of legal regulation that combines legal means, and more broadly, the elements of legal influence to create the desired social status.

The legal regime of integrity extends to both judicial and extrajudicial activities, and one that precedes judicial activity (including those for candidates).

The law introduced a strict regulation of ethical standards in the field of judicial activity, and the effectiveness of this will be revealed by further practice.

The thesis about the legal regime of integrity is substantiated. The consolidation of integrity as a term and legal relationship in normative legal acts, establishing it as an ethical principle of conduct and a positive legal obligation of integrity, forming also its legal regime. This regime is ensured by specific means of legal regulation.

The analysis makes it possible the following generalizations. Integrity in judicial activity is defined as a set of ethical principles and rules defined by law that should be guided by its subjects in judicial activity (including judges) in order to ensure confidence in their activity (for example, the administration of justice) that is the judicial exercise of the idea of law.

Key words: integrity, philosophy of law, general theory of law.

DOI: 10.36695/2219-5521.3.2019.03

УДК 340.15

\section{О.Ю. ІВAHOB}

Іванов Олександр Юрійович, кандидат юридичних наук, старший викладач Національної академії Служби безпеки України*

ORCID: 0000-0002-5890-5369

\section{ІОНІЧНА РЕСПУБЛІКА (1798-1807 РР.) В КОНТЕКСТІ ПОЛІТИКИ РОСІЙСЬКОГО ЕКСПАНСІОНІЗМУ: ІСТОРИКО-ПРАВОВИЙ АСПЕКТ}

У сучасній західній історіографії з історії Росії період кінця XVIII - початку XIX ст. ст. здобув назву «блискавичної експансії»: саме в цей час територія Російської імперії була розширена найбільше, і швидкість їі розширення була надзвичайно високою. Відповідно, для реалізації цих цілей царський уряд застосовував арсенал спеціальних методів, спрямованих на приєднання нових територій у найкоротший строк та за мінімальних витрат людських і матеріальних ресурсів. Приєднувані території були для Росії доволі важливими зі стратегічної точки зору, тому для включення їх до складу своїх володінь самодержавний уряд не гребував ніякими методами. Однією з таких територій підвищеного інтересу для російського імператора була Греція, а особливо - Іонічні острови, що увійшли до складу буферного союзу, відомого в історії як Республіка Семи Об’єднаних Островів (або Іонічна республіка) (1798 (1799)1-1807рp.).

У 1797 р. відбулося завоювання Іонічних островів армією французької Директорії під командуванням Наполеона Бонапарта. Тому в радянській і російській історіографії (Г. Арш ${ }^{2}$, А. Станіславська 3 , О. Шпаро ${ }^{4}$ та ін.) зайняття цих островів російською ескадрою під керівництвом адмірала Ф. Ушакова у 1798 р. характеризується не інакше, як «звільнення» їх із-під французького та турецького ярма. Українські ж історики (А. Пелешко 5 , Н. Терентьєва 6 , О. Терентьєва ${ }^{7}$ та ін.), зокрема середини 2000-х рр., відзначають зв'язок між пошуком греками союзників у боротьбі з французькою окупацією та приходом росіян як «визволителів»:

(C) О.Ю. Іванов, 2019

* Oleksandr Ivanov, Ph.D. in Law, Senior Lecturer of the National Academy of the Security Service of Ukraine 